\title{
New Frontiers in the Economics of Climate Change
}

\author{
Simon Dietz • David J. Maddison
}

Accepted: 12 February 2009 / Published online: 4 March 2009

(C) Springer Science+Business Media B.V. 2009

\section{Introduction}

The year 2009 promises to be decisive for climate policy. In December, 190 countries will gather in Copenhagen attempting to forge an agreement to succeed the Kyoto Protocol. Most prominently, they will attempt to reach agreement on reductions in greenhouse gas emissions. But the negotiations include a number of other important issues, such as the arrangements for industrialised countries to fund adaptation in developing countries. At the same time, the 44th President of the United States, Barack Obama, has promised a sea-change in White House policy, supporting national emissions targets and a cap-and-trade programme to deliver them. Yet all of this is proceeding against the backdrop of an unfolding global economic downturn, which at the time of writing is forecast to result in the weakest economic performance worldwide since 1945 (IMF 2009). The importance of climate-change economics should be clear.

This special issue of Environmental and Resource Economics was originally conceived as an 'adversarial collaboration' between an author of the Stern Review on the Economics of Climate Change (SD, contributing to Stern 2007), and a critic (DJM, in Maddison 2007). However, it is testament to the vitality of the discipline that our agenda for this issue has moved on. Rather than convening a symposium on the merits of the Stern Review (of which there have been several, in for instance Climatic Change, the Journal of Economic Literature, the Review of Environmental Economics and Policy, and World Economics), we collect together what are in our view some of the best examples of new economic research on climate change. Taken together, they look beyond the debate about the Stern Review and offer important insights for the design of future climate policy.

\footnotetext{
S. Dietz $(\varangle)$

Grantham Research Institute on Climate Change and the Environment and Department of Geography and Environment, London School of Economics and Political Science (LSE), Houghton Street, London, WC2A 2AE, UK

e-mail: s.dietz@1se.ac.uk

D. J. Maddison

Department of Economics, University of Birmingham, Edgbaston, Birmingham, B15 2TT, UK

e-mail: d.j.maddison@bham.ac.uk
} 
Zenghelis and Stern (2009) provide a preface to the issue. They set out what are in their view the key elements of a global deal on climate change that might be hammered out in Copenhagen. Three papers consider the impacts of climate change, and their valuation. Seo et al. (2009) investigate the impacts of climate change on agriculture in Africa. Leiter et al. (2009) examine the impact of flooding on the investment, employment and productivity of European firms. Anthoff and Tol (2009) develop a measure of the present value of the costs and benefits of emissions reductions, the 'balanced growth equivalent', used but not elaborated upon in the Stern Review. Their empirical results illustrate how much the costs and benefits of climate policy depend on disputed elements of the standard welfare-economic model.

A further four papers explore policies to reduce greenhouse gas emissions. Gerlagh et al. (2009) develop a model to investigate how the optimal rate of emissions taxation depends on innovation externalities, and the set of available policies to tackle them. Three papers go on to discuss elements of the (emerging) global carbon market. Convery (2009) chronicles the origins and development of the European Union Emissions Trading Scheme (EU ETS). Malueg and Yates (2009) also analyse the EU ETS, using a theoretical model to explore the incentives created by decentralising the supply of emissions allowances to EU member states. Finally, Larson and Breustedt (2009) analyse data from the pilot phase of the Clean Development Mechanism/Joint Implementation to test whether project finance flowed to where marginal abatement costs were lowest, or whether other factors prevented a cost-effective allocation.

We would like to sincerely thank all of the contributors. In our editorial, we highlight three themes. Firstly, we discuss the state of climate policy in 2009, in particular the implications of the global economic downturn. Secondly, we discuss the implications of a range of new research for the welfare economics of climate change. Thirdly, we identify a significant need for further research on the valuation of climate impacts.

\section{Climate Policy in 2009}

\subsection{Will Priorities Deferred Become Priorities Abandoned?}

The global downturn, which started as a financial crisis on Wall Street, has apparently demoted climate policies worldwide nearer to the bottom of the political agenda. It remains to be seen whether this will in turn diminish the prospects for meaningful reductions in carbon emissions, notwithstanding the fact that the downturn will itself temporarily arrest growth in those emissions. The December 2008 EU Council agreement on the climate and energy package gives mixed messages. On the one hand, the overall greenhouse gas emissions target of a $20 \%$ reduction below 1990 levels by 2020 has survived (rising to 30\% conditional on comparable efforts by other developed countries). On the other hand, concerns about the cost of emissions reductions seem to have postponed once more the EU's plan for wholesale auctioning of emissions allowances in the ETS. Together with other concessions, this important tenet of an efficient cap-and-trade scheme will not be achieved until at least 2020. Political negotiations in the United States may also stall. Whilst the Obama administration appears ready to push for a cap-and-trade programme, it will need to circumnavigate the same economic concerns. Some expect the overall emissions cap to hold, while hand-outs to affected firms (e.g. via free permits) will have to increase. ${ }^{1}$ In addition, comments made by Senator John Kerry make

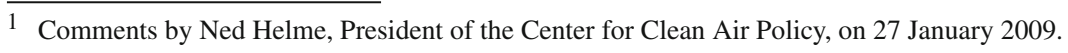


it clear that support for domestic cap-and-trade depends entirely on parallel commitments from developing countries such as India and China.

More broadly, one does not have to look far for evidence that policymakers believe, firstly, there is a tension between saving jobs and climate policy, and secondly, saving jobs is currently more important than reducing emissions. Canadian environment minister Jim Prentice warned: "We will not—and let me be clear on this—we will not aggravate an already weakening economy in the name of environmental progress. If this means re-examining the way forward in the face of present-day economic realities, then so be it". US Senator Claire McCaskill (Democrat) remarked "I' $m$ from a state [Missouri] where most of the people who turn on the lights in the state get it from utility companies that depend on coal. And the cost of switching all that to clean coal technology or to alternative sources is going to be borne by them, by regular folks who are trying to figure out how to pay their mortgages right now".

Nowhere have the consequences of the financial crisis spilling over into the real economy been felt more acutely than in the automobile industry. The European automobile industry claims that it cannot deal with the consequences of the credit crunch and decrease emissions at the same time. Proposed legislation, which is due to come into force across the EU in 2012, plans to fine carmakers whose vehicles fail to meet an emissions standard of $130 \mathrm{~g}$ of $\mathrm{CO}_{2}$ per $\mathrm{km}$. The industry is now vigorously lobbying to suspend the legislation, arguing that, with demand for vehicles collapsing, threatening them with financial penalties is not credible.

Measures to boost demand include paying owners of new cars to scrap their old cars, and the provision of state aid to car financing firms to help people raise money to buy a new car. This idea has already been implemented in Germany and is being actively discussed by the UK Treasury. It is far from clear that such measures will impact favourably on carbon emissions. In December the White House agreed to a \$17.4bn bailout for GM, Chrysler and Ford to help stave off bankruptcy. Later that same month the US Treasury unveiled a further \$6bn bailout for GMAC. Co-owned with Chrysler, GMAC's solvency was considered crucial to GM because it finances about $80 \%$ of GM dealers' wholesale car purchases. Experience suggests that measures to boost the demand for automobiles and save automobile manufacturers from bankruptcy either by handing out loans or weakening regulation will be difficult to remove or reverse after the present economic crisis has passed.

Elsewhere, member states of the EU are recovering from the gas dispute between Russia and Ukraine, which led to the temporary cessation of gas supplies to much of Europe, coinciding with an extended period of cold weather. Bulgaria and Slovakia have been hit particularly hard by the gas crisis, and Slovakia has indicated its desire to restart a nuclear power station dating from the Soviet era. In Sweden, the Government has abandoned a decades-old commitment to phase out nuclear power, concerned that renewable sources are not being developed quickly enough.

At the same time, despite cuts in production by OPEC, oil prices have fallen sharply from their 2008 peak of $\$ 147$ to only $\$ 40$ per barrel. Along with concerns over the aggregate demand, this has pushed the price of an EU ETS allowance down to little over $€ 10$ per tonne of $\mathrm{CO}_{2}$. While variations in permit prices are a fact of life in any cap-and-trade scheme, there are concerns about what effect currently low prices will have on already fragile incentives to invest in low-carbon technology.

\subsection{A ‘Green’ Fiscal Stimulus}

Having exhausted monetary policy, Governments are now turning to traditional Keynesian deficit spending to combat declining output and sharply rising unemployment. Taxes are 
being cut, infrastructure projects advanced and other forms of spending increased. Some believe that a fiscal stimulus can actually be combined with emissions reductions. A significant portion of Barack Obama's $\$ 838$ billion stimulus plan, which at the time of writing had just (narrowly) passed a vote in the Senate, is targeted at low-carbon investment, which, it is boldly claimed, will create up to 5 million 'green collar' jobs and revive the economy.

Combining fiscal stimulus with the pursuit of environmental quality might be misguided. John Whitehead comments that it makes much more sense to pursue fiscal policy without a green jobs constraint, and pursue environmental policy without a macroeconomic constraint. However, some measures to reduce emissions also seem to perform well against criteria for effective countercyclical spending. The Institute for Fiscal Studies (2008) sets out three such criteria. Measures should be (i) 'targeted', such that tax cuts and spending increases are focused on where the greatest increase in demand will result (i.e. having the greatest fiscal multiplier), and avoid sectors in which there are likely to be capacity constraints or skills shortages. They should be (ii) timely, in the obvious sense that measures should stimulate demand as quickly as possible after the shock, not requiring a long lead-time. And they should be (iii) temporary, such that financing stops before markets become concerned about the Government's ability to service its rising debt. Not all investments to reduce emissions will meet these three criteria. Nuclear power plants and demonstration projects of carbon capture and storage, for example, have very long lead-times. Renewable energy can be installed more rapidly and is comparatively labour-intensive at this stage in its development, but there may already be planning and capacity constraints limiting the ability to roll it out more quickly. However, other investments might meet the three criteria rather better, notably various energy efficiency measures, which can be deployed quickly and, the evidence would suggest, can boost domestic employment significantly (Roland-Holst 2008).

Even if doubts remain about the ability to align fiscal policy and climate policy during the downturn, it seems clear that investments should be avoided, which further lock economies into a high-carbon trajectory. Indeed, from a longer-run perspective it is important that any investments made to offset the current shock to aggregate demand should pass a social costbenefit test. This would avoid the caricature of 'crass Keynesianism', ${ }^{2}$ namely digging holes in the road and filling them in again. Recent economic growth in the developed world has been blighted by two unsustainable phenomena, the dot-com boom, followed by asset-price bubbles fuelled by cheap credit, especially in housing. Low-carbon investments will often pass a social cost-benefit analysis, based on our emerging understanding of the externality (see Anthoff et al. 2009, for the very latest estimates of the marginal damage cost of carbon). In other words they seem well placed to form part of a sustainable growth strategy.

\subsection{Key Research Issues}

Policy developments in 2009 are likely to have a lasting imprint, and set the tone for research priorities in the short to medium term. Cap-and-trade appears to be the only viable price instrument for carbon emissions, despite the reservations of many economists (e.g., Nordhaus 2007a). The momentum behind cap-and-trade has been building for a long time of course, but recent developments in the United States, Australia and beyond have cemented its rise. ${ }^{3}$ And given the current economic crisis, it is now very difficult to imagine politi-

2 Comments by Germany's finance minister Peer Steinbrück in Newsweek, 15 December 2008.

3 These reinforce each other given opportunities for arbitrage between regional schemes. 
cal success for any price instrument that does not create rents for firms. ${ }^{4}$ But as experience with emissions trading and project-based carbon finance accumulates, so our understanding of its weaknesses in reality will also build. Research continues to fruitfully address these weaknesses and make suggestions for improvement. In this issue, papers by Convery (2009) and by Malueg and Yates (2009) address aspects of the (imperfect) functioning of the EU ETS, while Larson and Breustedt (2009) assess the evidence on how efficiently the Clean Development Mechanism/Joint Implementation operated in its pilot phase.

Their findings tend to reinforce a general observation, namely that implementation of climate policy is never likely to attain the economic first-best, and is implemented against a backdrop of other policies that are themselves second-best. In this issue, Gerlagh et al. (2009) contribute to the debate about the relationship between price instruments and technology policies, showing how the price set in the former depends on the availability of effective examples of the latter.

\section{Climate Change and Welfare Economics}

\subsection{The Standard Welfare Model}

When Nicholas Stern described climate change as "the greatest market failure we have ever seen" (Stern 2007, p. 1), his first intention was not to create a sound bite (although over time it has served very well as just that). Rather, he aimed to articulate the unprecedented reach of the climate-change externality simultaneously over the dimensions of time, space, states of nature and elements of human well-being. Therefore it should come as no surprise that climate change has tested the meaning and relevance of the standard welfare-economic model to its limits.

This standard model, applied particularly in empirical analyses of optimal emissions such as those of Nordhaus (1994,2008; Nordhaus and Boyer 2000), is parsimonious, perhaps excessively so. Social welfare in this model is the simple sum of the utilities of all individuals in all time periods, weighted by the utility discount rate, and all states of nature, weighted by their probabilities. To render the model tractable, the utility of individuals in major regions of the world is aggregated into a single, representative individual and multiplied by the size of that region's population. There are typically a dozen world-regions or fewer. The representative individual lives for centuries, if not indeed forever. The utility of the representative individual in each region is described by an isoelastic function, where utility depends only on the aggregate consumption of goods and services. All of this effectively means that the parameter describing the curvature of the isoelastic utility function, formally the elasticity of the marginal utility of consumption, becomes a coefficient of (social) inequality aversion over space and time, as well as a coefficient of relative risk aversion, three very important and very general types of preference.

\subsection{Disentangling Risk Aversion, Inequality Aversion, and Intertemporal Substitution}

There are several ways to estimate the elasticity of the marginal utility of consumption, but all of them rely to a greater or lesser extent on forms of reasoning from first principle and on empirical evidence of various sorts. As it simultaneously represents three types of preference

4 Although this situation may reverse when the downturn bottoms out and concerns shift to repairing public budgets. 
that may be quite distinct ${ }^{5}$ (e.g. Barsky et al. 1997; Carlsson et al. 2005; Di Tella and MacCulloch 2006; Easterlin 1974), we are correspondingly presented with three equally valid lines of evidence on which to base its estimation, and these lines are often in contradiction. Thus in his review of the Stern Review, Gollier (2006) focuses on its role as a coefficient of relative risk aversion and argues that studies of insurance support elasticities of up to four or more. By contrast, studies of its role as a coefficient of social inequality aversion over space use evidence of income distribution to argue that even an elasticity of unity could be too high (e.g. Atkinson and Brandolini 2007). ${ }^{6}$ Both of these remain active and important areas of research, where a range of techniques from economics including those based on stated and revealed preferences can be applied.

It is not a priori clear what effect increases or decreases in the elasticity of the marginal utility of consumption will have on optimal emissions. A higher elasticity implies greater relative risk aversion, greater social inequality aversion over space, and greater social inequality aversion over time. The Stern Review team conducted some limited sensitivity analysis, looking at intertemporal substitution and relative risk aversion, but ignoring social inequality aversion over space. They found that increasing the elasticity from unity to two reduced the present value of the cost of climate change, but increasing it further from two to three did precisely the opposite (Dietz et al. 2007). Anthoff and Tol (2009) conduct further sensitivity analysis, and show that with the third dimension included, social inequality aversion over space, the present value of the cost of climate change rises with an increasing elasticity. This amply illustrates the limitations of the standard model. A high elasticity has been recommended as a way to generate an efficient social rate of time preference despite near-zero utility discounting (e.g. Dasgupta 2007: we return to this point below). Yet since this also modifies the relative rate of risk aversion and the rate of social inequality aversion over space, the results can be unexpected. Thus Anthoff and Tol conclude that the disentangling of risk aversion from inequality aversion and from intertemporal substitution is a priority for future research.

\subsection{The Relative Price of Environmental Goods and Services}

But the difficulties with the standard model are wider. One important consequence of the aggregation of all consumption goods and services into a single bundle, from which the monetary value of climate-change damage is subtracted in an additively separable framework, is the assumption that environmental goods and services are perfectly substitutable with 'man-made' goods and services. Put another way, the relative prices of environmental and man-made goods and services do not directly change. Yet as Hoel and Sterner (2007) and Sterner and Persson's (2008) show, the relative price of environmental goods and services should rise over time if, as seems reasonable, output of man-made goods and services continues to expand, while the resulting changes in climate limit the supply of environmental goods and services. ${ }^{7}$ In Sterner and Persson's (2008) empirical application, incorporating

\footnotetext{
5 Although Harsanyi (1955) and Broome (1991) have argued that, given certain assumptions, they may, as a matter of consistency, be very similar.

6 This study looked at distribution within a country. The elasticity implied by the propensity to give aid is even lower. It must also be remembered that the literature on project appraisal has generally been resistant to applying any kind of weighting to different income groups within society, effectively implying a determination to set an elasticity of zero where it concerns social inequality aversion over space (e.g. Harberger 1978).

7 In fact, this not only concerns final consumption; it is also an issue for the specification of production, where again integrated climate-economy models work with a single, composite capital stock.
} 
relative price changes into Nordhaus' DICE model (Nordhaus and Boyer 2000) increases the valuation of climate damages to such an extent that the optimal emissions path looks similar to that of the Stern Review, despite using Nordhaus' standard assumptions on discounting.

Ecological economists have long emphasised the issue of substitutability (e.g. Daly 1977) and in fairness environmental and resource economists have recognised it for just as long (Dasgupta and Heal 1979). The difficulty has been putting the concept into empirical operation. An integrated model of relative price change requires at a minimum (i.e. even for a model with just two goods, one environmental and the other produced) the parameterisation of concepts such as the elasticity of substitution between the composite environmental and man-made goods, and the initial share of the composite environmental good in the utility of the representative individual. We have very little information on the likely values of these parameters. Nevertheless the attention that Sterner and Persson's (2008) initial empirical sortie has generated (see e.g. Helm 2008) emphasises how important it is to persevere with one area of economic investigation where the inadequacy of the standard model is widely recognised and understood (compared with the issue of uncertainty, discussed below). We return to means of generating an evidence base below.

\subsection{The Limits of Expected-Utility Analysis}

It has long been understood by economists that the benefits and costs of climate policies cannot be estimated with certainty. Nevertheless as Heal and Kriström (2002) noted in their review of uncertainty and climate change, published in this journal, the bulk of the early work was deterministic. Notable exceptions included early attempts to estimate optimal emissions under uncertainty about costs and benefits (e.g. Nordhaus and Popp 1997; Pizer 1999), the implication of a possible climate catastrophe for policy intensity (e.g. Clarke and Reed 1994; Tsur and Zemel 1996), investigations into the option value in delaying irreversible investments in climate policy, where there is a prospect of learning (e.g. Kolstad 1996a,b; Manne and Richels 1995; Pindyck 2000; Ulph and Ulph 1997), and investigations into how benefit and cost uncertainty affect instrument design (e.g. Pizer 1999).

However, what has recently become evident is that uncertainty about climate policy is greater, and of a less mathematically convenient form, than previously thought. A paper by Weitzman (2009) has focused attention on the matter. Weitzman's analysis is motivated by the large uncertainty around estimates of the climate sensitivity (i.e. commonly the equilibrium increase in global mean temperature for a doubling in the atmospheric stock of carbon dioxide), in particular by the long tail in the distribution of climate sensitivities, which, if realised, would bring about a rate of global warming unprecedented not just in human but indeed in geological history. ${ }^{8}$ Roe and Baker (2007) show that the risk is essentially due to the role of positive feedbacks. Together with further uncertainties about, for example, future emissions, the existence of such uncertainty about the climate sensitivity renders the assumption, necessary for expected-utility analysis, that we 'know' the probability distribution of climate impacts, very strong indeed.

Still operating within an expected-utility framework, Weitzman relaxes this assumption somewhat and considers the effect of uncertainty about the probability distribution of climate impacts. The decision-maker begins with a prior distribution of climate-change damage that has unknown and unbounded variance (this is his uninformative Bayesian prior). The decision-maker learns about this distribution using research data, but when the probability

8 According to Weitzman (2009), the probability that a generalised notion of the climate sensitivity, including large-scale positive feedbacks from the carbon cycle, exceeds $10^{\circ} \mathrm{C}$ is about $5 \%$, and it is about $1 \%$ for exceeding $20^{\circ} \mathrm{C}$. 
distribution is updated, the expected cost of climate change remains unbounded. The probability of high consumption losses due to climate change declines less rapidly than the marginal utility of consumption increases. For any utility function with strictly positive relative risk aversion, the marginal cost of climate change is infinity if the marginal utility of consumption wins this 'convergence race', so-to-speak. We should thus have an infinite willingness to pay for reducing greenhouse gas emissions. Elements of this result were previously identified in an empirical study by Tol (2003).

The implications of all this are difficult. As Nordhaus' (2007b) points out, we are not infinitely willing to pay for anything, let alone climate policy. Weitzman himself shows that one way to circumvent his result is to impose an arbitrary upper bound on the cost of climate change, analogous to the value of a statistical life, but rather grander: "the value of statistical civilization as we know it or maybe even the value of statistical life on Earth as we know it" (p. 6). The problem we now have, though, is that results are likely to depend in some important measure on where exactly the rather arbitrary (and unknown) upper bound is set, given the behaviour of the isoelastic utility function with strictly positive relative risk aversion at very low levels of consumption. This is indeed Nordhaus' (2007b) point, namely that perhaps what we have learned above all is the limited meaning of isoelastic utility under these circumstances. Heal (2008), in his excellent 'meta-review' of the debate about the Stern Review, raises wider questions. He notes that in a sense Weitzman applies expected-utility analysis to a problem, for which one would not anticipate expected-utility analysis to be suited. Rather he points to the work of Henry and Henry (2002), and various recent attempts to work through the economics of ambiguity beyond expected utility (e.g. Maccheroni et al. 2006). Indeed, a further drawback with the expected-utility model is that it has not necessarily proved to be a good model of human behaviour, or a good predictor of market outcomes (see Quiggin 2008, for a topical summary). Clearly research on the many extensions of expected-utility analysis is of a high priority.

\subsection{Intergenerational Equity and Discounting}

The aspect of the welfare economics of climate change that has attracted the strongest exchanges since publication of the Stern Review has been intergenerational equity, and how it is represented by the discount rate. The participants in this debate have variously accused each other of ignorance of the body of work on public economics (see Stern 2008), 'subconsciously' undertaking analysis to confirm the policy position of the UK Government (see Weitzman 2007), and even trying to rekindle the British Empire (see Nordhaus 2007c).

As is by now well known the debate is between those who adopt a 'descriptive' approach to discounting, using market data to try to ensure efficiency across investments across time (e.g. Dasgupta 2007; Nordhaus 2007c; Weitzman 2007), and those who adopt a 'prescriptive' approach, setting the parameters of the social discount rate based on first principles to ensure what they perceive to be a prima facie fair allocation of resources between generations (e.g. Stern 2007). The descriptive approach tends to give a higher discount rate than the prescriptive approach. In the Stern Review, the utility discount rate was infamously nearly zero, while the social discount rate was on average circa just $1.4 \%$.

To seasoned observers, it would seem that history is repeating itself, given that much the same stand-off accompanied the near contemporaneous publication of Cline's (1992) and Nordhaus' (1994) first appraisals of climate policy. ${ }^{9}$ Certainly a great deal of progress has been made in the field of discounting since then, for instance on hyperbolic discount-

\footnotetext{
9 Gerlagh made this observation in a special session on discounting at the 2008 EAERE conference in Gothenburg. There was also a spirited debate in the 1970s culminating in the publication of Lind (1982).
} 
ing (e.g. Frederick et al. 2002; Harris and Laibson 2001), and on declining discount rates under uncertainty about future growth (Gollier 2001; Weitzman 1998). Yet lacunae remain, for what concerns many philosophers is the fundamental issue of representation of future generations, and appropriate principles for incorporating their interests (e.g. Caney 2008). From this perspective, unequal valuation of the welfare of different generations via some positive utility discount rate is difficult to justify. A time-declining discount rate might be of some help in this respect (it reduces the very long-run rate of discount), but this would be largely coincidental to the philosophers' concerns. Equally, the prescriptive approach is not without its loose ends either. If, for instance, we are to have a very low discount rate for climate change, should we not have a similarly low discount rate for other long-run public investments such as nuclear energy? Or is there something special about climate policy? The great old discounting debate will rumble on for some time yet.

\section{Valuing the Impacts of Climate Change}

Cost-benefit analyses of measures to combat climate change such as the Stern Review (Stern 2007) depend, amongst other things, on estimates of the costs of carbon abatement and the benefits in terms of the damage avoided. Surprisingly little continues to be known, however, about people's preferences for a particular climate or their willingness to pay to avoid negative impacts of climate change. Likewise, we continue to know very little about the role if any that climate plays in the production of marketed goods and services, which also limits our ability to deploy more sophisticated models of climate policy, as discussed above. Do households have preferences for particular types of climate? How do households reveal their preferences for particular types of climate? Will economic agents necessarily be damaged by climate change or will some gain and if so who and by how much? What is the income elasticity of willingness to pay for climate amenities? Answering these questions is hugely important for policy purposes.

The most obvious approach to tackling these valuation questions is the hedonic technique. If households are able to select from differentiated localities then climate itself becomes a choice variable. The tendency will be for the costs and benefits associated with particular climates to become capitalised into property prices and wages. This same technique has been used to value the impact of climate change on agriculture (e.g. Mendelson et al. 1994). Unfortunately climate variables only vary over large distances, at which point key underlying assumptions of the technique (perfect information and absent barriers to mobility) become untenable.

In the household production-function approach (e.g. Maddison 2003), household cost functions are estimated on observed expenditure data. Such an approach is customarily used to calculate the needs of households with differing demographic composition, with the results reported in the form of equivalence scales. In the hypothetical equivalence scales approach, by contrast, individuals are asked about the minimum after-tax income necessary for a household in identical circumstances to reach a specified standard of living (e.g. 'comfortable' or 'sufficient'). Van Praag (1988) presents hypothetical equivalence scales for households in Europe, showing that climate variables affect the cost of living.

Recently economists such as Layard (2006) have started to use such studies to examine whether growth makes people happy and whether inflation and unemployment make individuals unhappy. Analyses of the economic determinants of happiness or subjective well-being now appear with regularity in top economics journals. Although it appears very difficult to explain cross-country differences in average happiness scores, Rehdanz and Maddison (2005) use cross-country data on subjective wellbeing to analyse preferences for climate. 
Despite differences in the geographical context, the quality of the data employed and the plausibility of the underlying assumptions, these studies uniformly indicate that climate is rather important to household welfare. The small number of studies is testament to the enduring antipathy towards valuing the impact of climate change in monetary terms, and instinctive opposition to the idea that climate change may in fact not be detrimental to all countries. There is abundant scope for more elaborate attempts to estimate the amenity value of climate to households (and firms) using spatially referenced data drawn from climatically heterogeneous zones.

Hedonic techniques could, for example, be used to value anthropogenically-induced changes in flood risk by linking spatially referenced information on house prices to flood risk maps, as has been done in the United States. Most importantly, if the goal of such studies is to inform global cost-benefit analyses, the results must be combined with climate-change scenarios and the damage costs aggregated over countries. Without this final critical step, studies into the amenity value of climate to households and firms will not generally contribute to the debate. In this volume, Seo et al. (2009) merge survey data collected from African agriculturalists with hydrological, climate, and soil-survey data, whereas Leiter et al. (2009) combine spatially-referenced data on European firms with information on flooding.

Acknowledgements SD would like to acknowledge the financial support of the Grantham Foundation for the Protection of the Environment, as well as the Centre for Climate Change Economics and Policy, which is funded by the UK's Economic and Social Research Council (ESRC) and Munich Re.

\section{References}

Anthoff D, Tol RSJ (2009) The impact of climate change on the balanced-growth-equivalent: an application of FUND. Environ Resour Econ. doi:10.1007/s10640-009-9264-s

Anthoff D, Tol RSJ, Yohe GW (2009) Discounting for climate change. Economics Discussion Papers 2009-15

Atkinson T, Brandolini A (2007) On analysing the world distribution of income. Oxford University

Barsky RB, Juster FT, Kimball MS, Shapiro MD (1997) Preference parameters and behavioral heterogeneity: an experimental approach in the health and retirement study. Q J Econ 112(2):537-579. doi:10.1162/ 003355397555280

Broome J (1991) Weighing goods. Cambridge, Mass, Basil Blackwell

Caney S (2008) Human rights, climate change, and discounting. Env Polit 17(4):536-555. doi:10.1080/ 09644010802193401

Carlsson F, Daruvala D, Johansson-Stenman O (2005) Are people inequality-averse, or just risk-averse? Economica 72(287):375-396. doi:10.1111/j.0013-0427.2005.00421.x

Clarke HR, Reed WJ (1994) Consumption/pollution tradeoffs in an environment vulnerable to pollution-related catastrophic collapse. J Econ Dyn Control 18(5):991-1010. doi:10.1016/0165-1889(94)90042-6

Cline WR (1992) The economics of global warming. Institute for International Economics, Washington

Convery F (2009) Origins and development of the EU ETS. Environ Resour Econ doi:10.1007/ s10640-009-9275-7

Daly HE (1977) Steady-state economics: the economics of biophysical equilibrium and moral growth. W. H. Freeman, San Francisco

Dasgupta P (2007). Discounting climate change. University of Cambridge

Dasgupta P, Heal G (1979) Economic theory and exhaustible resources. Cambridge University Press, Cambridge

Dietz S, Hope C, Patmore N (2007) Some economics of 'dangerous' climate change: reflections on the Stern Review. Glob Environ Change 17(3-4):311-325. doi:10.1016/j.gloenvcha.2007.05.008

Di Tella R, MacCulloch R (2006) Some uses of happiness data in economics. J Econ Perspect 20(1):25-46. doi:10.1257/089533006776526111

Easterlin RA (1974) Does economic growth improve the human lot? Some empirical evidence. In: David PA, Reder MW (eds) Essays in honor of Moses Abramovitz. Academic Press, New York pp 89-125

Frederick S, Loewenstein G, O'Donoghue T (2002) Time discounting and time preference: a critical review. J Econ Lit 40(2):351-401. doi:10.1257/002205102320161311 
Gerlagh R, Kverndokk S, Rosendahl KE (2009) Optimal timing of climate change policy: interaction between carbon taxes and innovation externalities. Environ Resour Econ doi:10.1007/s10640-009-9271-y

Gollier C (2001) The economics of risk and time. MIT Press, Cambridge, Mass

Gollier C (2006) Institute outlook: climate change and insurance: an evaluation of the Stern report on the economics of climate change, Barbon Institute

Harberger AC (1978) On the use of distributional weights in social cost-benefit analysis. J Polit Econ 86(S2):S87-S120. doi:10.1086/260696

Harris C, Laibson D (2001) Dynamic choices of hyperbolic consumers. Econometrica 69(4):935-957. doi:10. $1111 / 1468-0262.00225$

Harsanyi JC (1955) Cardinal welfare, individualistic ethics, and interpersonal comparisons of utility. J Polit Econ 63(4):309-321. doi:10.1086/257678

Heal G (2008) Climate economics: a meta-review and some suggestions for future research. Rev Environ Econ Policy 3(1):4-21. doi:10.1093/reep/ren014

Heal G, Kriström B (2002) Uncertainty and climate change. Environ Resour Econ 22(1-2):3-39. doi:10.1023/ A: 1015556632097

Helm D (2008) Climate-change policy: why has so little been achieved? Oxf Rev Econ Policy 24(2):211-238. doi:10.1093/oxrep/grn014

Henry C, Henry M (2002) Formalization and applications of the precautionary principle. Discussion Paper 2002009. Louvain, Belgium, Université Catholique de Louvain, Institut de Recherches Economiques et Sociales

Hoel M, Sterner T (2007) Discounting and relative prices. Clim Change 84(3-4):265-280. doi:10.1007/ s10584-007-9255-2

IMF (2009) Global economic slump challenges policies. World Economic Outlook (WEO). Update January 28th 2009. Washington, DC, IMF

Institute for Fiscal Studies (2008) Pre-Budget report. London, Institute for Fiscal Studies

Kolstad C (1996a) Fundamental irreversibilities in stock externalities. J Public Econ 60:221-233. doi:10.1016/ 0047-2727(95)01521-3

Kolstad C (1996b) Learning and stock externalities in environmental regulations: the case of greenhouse gas emissions. J Environ Econ Manag 31:1-18. doi:10.1006/jeem.1996.0028

Larson DF, Breustedt G (2009). Will markets direct investments under the Kyoto Protocol? Lessons from the activities implemented jointly pilots. Environ Resour Econ doi:10.1007/s10640-009-9272-X

Layard R (2006) Happiness: lessons from a new science. Penguin, London

Leiter AM, Oberhofer H, Raschky P (2009) Creative disasters? Flooding effects on capital, labour and productivity within European firms. Environ Resour Econ doi:10.1007/s10640-009-9273-9

Lind RC (ed) (1982) Discounting for time and risk in energy policy. Washington, D.C.; Baltimore, Resources for the future; Distributed by the Johns Hopkins University Press

Maccheroni F, Marinacci M, Rustichini A (2006) Ambiguity aversion, robustness, and the variational representation of preferences. Econometrica 74(6):1447-1498. doi:10.1111/j.1468-0262.2006.00716.x

Maddison DJ (2003) The amenity value of climate: the household production function approach. Resour Energy Econ 25:155-175. doi:10.1016/S0928-7655(02)00024-6

Maddison DJ (2007) Further comments on the Stern Review. Mimeo. University of Birmingham, Birmingham, UK

Malueg DA, Yates AJ (2009) Strategic behavior, private information, and decentralization in the European Union Emissions Trading System. Environ Resour Econ doi:10.1007/s10640-009-9274-8

Manne A, Richels R (1995) The greenhouse debate: economic efficiency, burden sharing and hedging strategies. Energy J 16(4):1-37

Mendelsohn RO, Nordhaus WD, Shaw D (1994) The impact of global warming on agriculture: a Ricardian analysis. Am Econ Rev 84:753-771

Nordhaus WD (1994) Managing the global commons: the economics of climate change. MIT Press, Cambridge, Mass

Nordhaus WD (2007a) To tax or not to tax: alternative approaches to slowing global warming. Rev Environ Econ Policy 1(1):26-44. doi:10.1093/reep/rem008

Nordhaus WD (2007b) The real meaning of Weitzman's dismal theorem. Mimeo. Yale University, New Haven, CT

Nordhaus WD (2007c) A review of the Stern review on the economics of climate change. J Econ Lit 45(3):686702. doi: $10.1257 /$ jel.45.3.686

Nordhaus WD (2008) A question of balance: weighing the options on global warming policies. Yale University Press, New Haven and London

Nordhaus WD, Boyer J (2000) Warming the world: economic models of global warming. MIT Press, Cambridge, Mass 
Nordhaus WD, Popp D (1997) What is the value of scientific knowledge? An application to global warming using the PRICE model. Energy J 18:1-47

Pearce DW, Ulph D (1999) A social discount rate for the United Kingdom. In: Pearce DW (ed) Environmental economics: essays in ecological economics and sustainable development. Cheltenham, Edward Elgar pp 268-285

Pindyck R (2000) Irreversibilities and the timing of environmental policy. Resour Energy Econ 22:233-259. doi:10.1016/S0928-7655(00)00033-6

Pizer WA (1999) The optimal choice of climate change policy in the presence of uncertainty. Resour Energy Econ 21:255-287. doi:10.1016/S0928-7655(99)00005-6

Quiggin J (2008) Stern and his critics on discounting and climate change: an editorial essay. Clim Change 89(3-4):195-205. doi:10.1007/s10584-008-9434-9

Rehdanz K, Maddison DJ (2005) Climate and happiness. Ecol Econ 52:111-125. doi:10.1016/j.ecolecon. 2004.06.015

Roe GH, Baker MB (2007) Why is climate sensitivity so unpredictable. Science 318:629-632. doi:10.1126/ science. 1144735

Roland-Holst D (2008) Energy efficiency, innovation, and job creation in California. Center for Energy, Resources and Economic Sustainability, University of California, Berkeley

Seo SN, Mendelsohn R, Dinar A, Hassan R, Kurukulasuriya P (2009) A Ricardian analysis of the distribution of climate change impacts on agriculture across agro-ecological zones in Africa. Environ Resour Econ doi:10.1007/s10640-009-9270-z

Stern N (2007) The economics of climate change: the Stern review. Cambridge University Press, Cambridge UK

Stern N (2008) The economics of climate change. Am Econ Rev 98(2):1-37. doi:10.1257/aer.98.2.1

Sterner T, Persson UM (2008) An even Sterner review: introducing relative prices into the discounting debate. Rev Environ Econ Policy 2(1):61-76. doi:10.1093/reep/rem024

Tol RSJ (2003) Is the uncertainty about climate change too large for expected cost-benefit analysis. Clim Change 56:265-289. doi:10.1023/A:1021753906949

Tsur Y, Zemel A (1996) Accounting for global warming risks: resource management under event uncertainty. J Econ Dyn Control 20(6-7):1289-1305. doi:10.1016/0165-1889(95)00900-0

Ulph A, Ulph D (1997) Global warming, irreversibility and learning. Econ J 107:636-650. doi:10.1111/ 1468-0297.00181

van Praag BMS (1988) Climate equivalence scales: an application of a general method. Eur Econ Rev 4:10191024. doi:10.1016/0014-2921(88)90059-1

Weitzman ML (1998) Why the far distant future should be discounted at its lowest possible rate. J Environ Econ Manag 36:201-208. doi:10.1006/jeem.1998.1052

Weitzman ML (2007) A review of the Stern review on the economics of climate change. J Econ Lit 45(3):703724. doi: $10.1257 /$ jel.45.3.703

Weitzman ML (2009) On modelling and interpreting the economics of catastrophic climate change. Rev Econ Stat 91(1):1-19. doi:10.1162/rest.91.1.1

Zenghelis D, Stern N (2009) Principles for a global deal for limiting the risks from climate change. Environ Resour Econ doi:10.1007/s10640-009-9277-5 